\title{
Correction to: TGFB-induced factor homeobox 1 (TGIF) expression in breast cancer
}

\author{
Christine Stürken ${ }^{1}$, Volker Möbus ${ }^{2}$, Karin Milde-Langosch ${ }^{3}$, Sabine Schmatloch ${ }^{4}$, Peter A. Fasching ${ }^{5}$, Josef Rüschoff ${ }^{4}$, \\ Elmar Stickeler ${ }^{6}$, Rolf-Peter Henke ${ }^{7}$, Carsten Denkert ${ }^{8}$, Lars Hanker ${ }^{9,12}$, Christian Schem ${ }^{10}$, Valentina Vladimirova ${ }^{11}$, \\ Thomas Karn ${ }^{12}$, Valentina Nekljudova ${ }^{11}$, Claus-Henning Köhne ${ }^{7}$, Frederik Marmé ${ }^{13}$, Udo Schumacher ${ }^{1}$, \\ Sibylle Loibl ${ }^{11}$ and Volkmar Müller ${ }^{3^{*}}$
}

\section{Correction to: BMC Cancer 21, 920 (2021) https://doi.org/10.1186/s12885-021-08656-0}

Following publication of the original article [1], the authors noticed an incorrect affiliation for Christine Stürken and Udo Schumacher. The correct affiliations are as follows:

Christine Stürken

Institute of Anatomy and Experimental Morphology, University Medical Center Hamburg-Eppendorf, Martinistrasse 52, 20246 Hamburg, Germany.

Udo Schumacher

Institute of Anatomy and Experimental Morphology, University Medical Center Hamburg-Eppendorf, Martinistrasse 52, 20246 Hamburg, Germany.

The affiliations have been correctly published in this correction and the original article [1] has been updated.
Hospital of Schleswig-Holstein, Campus Lübeck, Kiel, Germany.

${ }^{10}$ Mammazentrum Hamburg, Hamburg, Germany. ${ }^{11}$ German Breast Group, Neu-Isenburg, Germany. ${ }^{12}$ Goethe University, Frankfurt, Germany.

${ }^{13}$ Medizinische Fakultät Mannheim, Universität Heidelberg,

Universitätsfrauenklinik Mannheim, Mannheim, Germany.

Published online: 15 September 2021

\section{Reference}

1. Stürken C, Möbus V, Milde-Langosch K, Schmatloch S, Fasching PA, Rüschoff $J$, et al. TGFB-induced factor homeobox 1 (TGIF) expression in breast cancer. BMC Cancer. 2021;21(1):920. https://doi.org/10.1186/s12885-021-08656-0.

\begin{abstract}
Author details
'Institute of Anatomy and Experimental Morphology, University Medical Center Hamburg-Eppendorf, Martinistrasse 52, 20246 Hamburg, Germany. ${ }^{2}$ Klinik für Gynäkologie und Geburtshilfe, Klinikum Frankfurt Höchst GmbH, Frankfurt am Main, Germany. ${ }^{3}$ Department of Gynecology, University Medical Center Hamburg-Eppendorf, Martinistrasse 52, 20246 Hamburg, Germany. ${ }^{4}$ Elisabeth Krankenhaus Kassel, Kassel, Germany. ${ }^{5}$ Universitätsklinikum Erlangen, Erlangen, Germany. ${ }^{6}$ Uniklinik RWTH Aachen, Aachen, Germany. ${ }^{7}$ Klinikum Oldenburg, Oldenburg, Germany. ${ }^{8}$ Institute of Pathology, Philipps-University Marburg and University Hospital Marburg (UKGM), Marburg, Germany. ${ }^{9}$ Department of Gynecology and Obstetrics, University
\end{abstract}

The original article can be found online at https://doi.org/10.1186/s12885021-08656-0.

*Correspondence: vmueller@uke.de

${ }^{3}$ Department of Gynecology, University Medical Center Hamburg-Eppendorf, Martinistrasse 52, 20246 Hamburg, Germany

Full list of author information is available at the end of the article

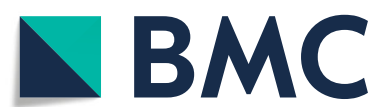

(-) The Author(s). 2021 Open Access This article is licensed under a Creative Commons Attribution 4.0 International License, which permits use, sharing, adaptation, distribution and reproduction in any medium or format, as long as you give appropriate credit to the original author(s) and the source, provide a link to the Creative Commons licence, and indicate if changes were made. The images or other third party material in this article are included in the article's Creative Commons licence, unless indicated otherwise in a credit line to the material. If material is not included in the article's Creative Commons licence and your intended use is not permitted by statutory regulation or exceeds the permitted use, you will need to obtain permission directly from the copyright holder. To view a copy of this licence, visit http://creativecommons.org/licenses/by/4.0/ The Creative Commons Public Domain Dedication waiver (http://creativecommons.org/publicdomain/zero/1.0/) applies to the data made available in this article, unless otherwise stated in a credit line to the data. 